\title{
KAJIAN FILOSOFIS TERHADAP STANDAR PERILAKU ETIS NOTARIS
}

\author{
Supriyanta \\ Fakultas Hukum Universitas Slamet Riyadi Surakarta \\ Jalan Sumpah Pemuda No.18 Joglo, Kadipiro Surakarta \\ E-mail: superprian@gmail.com \\ Abstract
}

A notary bound norms and values that constitute the parameters behave ethically. Philosophically, there is a size that is not universally applicable in the world of ethical behavior parameters notary. In a more concrete level, and factual measures for ethical behavior is a notary public Notary code of Ethics. In order to realize a notary ethical behavior, integrity and commitment required in the process of enforcement of the code Notary substance through a mechanism that has been agreed. This process must be done continuously so that woke standards of ethical behavior that can guide behavior that is not only derived from the text of the Notary Code, but also from a contextual understanding of the implementation of the Notary code of Ethics. Notary code of Ethics as the only parameter Notary ethical behavior in the sense that the most factual, should always be tailored to the developmental dynamics that occur in the community, so that the values contained in it maintained its existence.

Keyword: Philosopycal Analysis, Ethical Standards Of Conduct Notary

\section{A. Pendahuluan}

Di bidang hukum, telah berkembang profesi hukum, salah satu diantaranya adalah profesi notaris. Sebuah profesi menurut Soetandyo Wignyosubroto selalu ditandai oleh : kegiatan pelayanan jasa atas dasar pembayaran upah atau honoraris; penggunaan kecakapan teknis yang tinggi, dan karenanya harus dipenuhi oleh suatu pendidikan khusus yang formil; dan landasan kerja yang ideal, dan disokong oleh cita-cita etis masyarakat (Wawan Tunggul Alam, 2004 : 19).

Di bidang hukum perdata, hadirnya profesi notaris memiliki arti yang sangat penting dalam kehidupan sosial. la adalah pembuat dokumen yang kuat dalam suatu proses hukum ( Tan Thong Kie, 2007 : 444). Menurut Undang-Undang No. 30 Tahun 2004 tentang Jabatan Notaris, Pasal 1 disebutkan : "Notaris adalah pejabat umum yang berwenang untuk membuat akta otentik dan kewenangan lainnya sebagaimana dimaksud dalam undang-undang ini." Pejabat umum adalah orang yang menjalankan sebagian fungsi publik dari negara, khususnya di bidang hukum perdata. Sebagai sebuah profesi yang salah satu karakteristiknya adalah memiliki kode etik, maka notaris dalam menjalankan tugas profesinya harus mematuhi kode etik notaris dan peraturan perundang-undangan lainnya yang berlaku bagi notaris.

Notaris merupakan salah satu profesi yang menjalankan pelayanan hukum kepada masyarakat luas, yang memiliki tanggung jawab berkenaan dengan alat bukti otentik berupa suratsurat, akta-akta maupun dokumen yang dibuatnya

Yustisia Vol.2 No.3 September - Desember 2013 secara tertulis atas berbagai perbuatan hukum. Posisi notaris sangat penting dalam membantu menciptakan kepastian dan perlindungan hukum bagi masyarakat. Notaris memiliki kedudukan yang sangat strategis dalam ranah hukum perdata, karena profesi ini menyangkut urusan paling pokok dan sangat mendasar dalam setiap perbuatan hukum, terutama bidang hukum perdata. Masyarakat yang menjadi subyek sekaligus obyek dari setiap perbuatan hukum akan sangat terbebani dengan urusan administrasi hukum. Dokumen-dokumen yang berhubungan dengan perbuatan-perbuatan hukum yang akan dilakukan tidak akan tersusun secara benar dan sesuai prosedur hukum, jika dikerjakan oleh orang yang bukan ahli dan benar-benar menguasai bidang tersebut, karena itulah para notaris hadir dan menawarkan jasa untuk membantu masyarakat.

Undang-Undang Jabatan Notaris telah mempergunakan secara bersama-sama institusi Notaris sebagai Jabatan (Jabatan Notaris) dan Notaris sebagai Profesi (Profesi Notaris) atau istilah tersebut dipersamakan (setara) penggunaannya (Habib Adjie, 2009 : 7). Pasal 1 angka 1 Undang-Undang Jabatan Notaris (UUJN) menentukan bahwa Notaris adalah Pejabat Umum yang berwenang untuk membuat akta otentik dan kewenangan lainnya sebagaimana dimaksud dalam Pasal 15 UUJN. Kedudukan notaris sebagai pejabat umum dalam arti kewenangan yang ada pada notaris tidak pernah diberikan kepada pejabat-pejabat lainnya selama-sepanjang kewenangan tersebut tidak menjadi kewenangan pejabat-pejabat lain dalam membuat akta otentik 
dan kewenangan lainnya, maka kewenangan tersebut menjadi kewenangan Notaris (Habib Adjie, 2009 : 40).

Notaris diangkat sebagai pejabat umum, bukan untuk kepentingan dirinya, namun untuk melayani masyarakat dalam bidang hukum perdata. Pekerjaan notaris bukanlah pekerjaan biasa yang semata-mata mencari nafkah. Namun pekerjaan notaris merupakan panggilan untuk mengabdi kepada kemanusiaan, disamping harus bekerja secara profesional dan mempunyai sikap yang luhur demi menjaga martabat jabatannya. Notaris diharapkan memiliki posisi netral, sehingga dalam melaksanakan tugas profesinya untuk dan atas permintaan kliennya. Dalam hal melakukan tindakan hukum untuk kliennya, notaris juga tidak boleh memihak kliennya, karena tugas notaris ialah untuk mencegah terjadinya masalah.

Melihat pekerjaan dan fungsi notaris yang begitu vital diantaranya adalah memberikan kepastian hukum bagi para pihak, menjadi sangat berbahaya jika seorang notaris dalam menjalankan profesinya melakukan tindakan tercela, seperti ikut membantu memanipulasi data dan fakta demi kepentingan salah satu pihak, sehingga dapat merugikan pihak lainnya ( Wawan Tunggul Alam 2004:93). Oleh karena itu pula, seorang notaris yang seringkali dipanggil menghadap ke Pengadilan karena suatu kasus tertentu, misalnya untuk menerangkan akta yang telah dibuatnya, atau terlebih lagi jika sempat terlibat menjadi pelaku dalam suatu kasus pidana, jelas mengurangi kredibilitas notaris tersebut di mata masyarakat.

Notaris harus bersikap profesional artinya notaris harus mempunyai keahlian/kemahiran teknis yang bermutu tinggi, disertai rasa tanggung jawab, menjamin kepastian hukum, bekerja tanpa pamrih dengan menjauhkan kepentingan pribadinya serta bersikap adil bagi kliennya. Notaris yang bekerja secara profesional harus mematuhi etika profesi notaris, dengan kata lain seorang notaris dalam melakukan pekerjaan profesinya harus mampu menunjukkan perilaku yang etis. Seorang notaris dalam memberikan pelayanan harus mempertahankan cita-cita luhur profesi sesuai dengan tuntutan kewajiban hati nurani (Abdulkadir Muhammad, 2001: 60). Berdasarkan uraian di atas, permasalahan yang patut diajukan adalah seperti apakah hakikat standar perilaku etis notaris serta faktor apakah yang mempengaruhi perilaku etis notaris dalam menjalankan tugasnya selaku pejabat umum?

\section{B. Filsafat, Etika dan Profesi Hukum}

Menurut pandangan Theo Huijbers (1995) filsafat adalah kegiatan intelektual yang metodis dan sistematis, secara refleksi menangkap makna yang hakiki keseluruhan yang ada. Obyek filsafat bersifat universal, mencakup segala yang dialami oleh manusia. Berpikir secara filsafat adalah mencari arti segala yang ada melalui pandangan yang paling luas. Sementara itu Sumaryono (1995) menjelaskan bahwa filsafat adalah ilmu yang berfungsi sebagai interpretasi tentang hidup manusia, tugasnya adalah meneliti dan menentukan semua fakta konkrit sampai pada yang paling mendasar. Ciri khasnya adalah dalam menjawab pertanyaan selalu menimbulkan pertanyaan baru.

Istilah etika, etis dan moral sering dipergunakan orang dalam keseharian karena persoalan etika dan moral bersentuhan langsung dengan kehidupan manusia. Etika merupakan bagian dari filsafat, sedangkan filsafat adalah suatu interpretasi mengenai hidup manusia yang mempunyai tugas meneliti dan menentukan semua fakta konkrit sampai kepada dasarnya yang paling dalam. (Muchsin, 2004 : 66). Selain itu makna etika juga merupakan predikat atas perbuatanperbuatan seseorang. Karena itu seringkali etika juga dipandang sebagai ilmu pengetahuan yang menetapkan ukuran-ukuran atau kaidah-kaidah yang mendasari pemberian tanggapan atau penilaian terhadap perbuatan-perbuatan (Louiss O. Kattsoft : 352). Bender mengatakan filsafat adalah genus, filsafat etika adalah spesies ( Othe Salman, $2010: 7$ )

Etika merupakan sistem nilai-nilai dan norma-norma moral yang menjadi pedoman bagi individu atau suatu kelompok dalam mrngatur tingkah lakunya. Etika bertujuan agar orang hidup bermoral baik dan berkepribadian, sesuai dengan etika moral yang dianut oleh kesatuan atau lingkungan hidupnya. Etika moral ini menimbulkan norma-norma etika yang mencakup teori nilai tentang hakikat yang baik dan yang buruk dan teori tentang perilaku tentang perbuatan mana yang baik dan yang buruk.Sedangkan istilah etika profesi hukum berkaitan dengan ilmu tentang kesusilaan, mengenai yang baik dan buruk, yang patut atau tidak patut dilakukan oleh seseorang dalam jabatannya sebagai pelaksana hukum termasuk di sini adalah seorang notaris. Seorang profesional hukum menurut Notohamidjojo (1975) dalam melaksanakan kewajibannya perlu memiliki :Sikap manusiawi, artinya menyikapi hukum tidak hanya secara formal melainkan kebenaran yang sesuai dengan hati nurani, sikap adil artinya mencari kelayakan yang sesuai 
dengan perasaan masyarakat, sikap patut artinya mencari pertimbangan untuk menentukan keadilan dalam suatu perkara konkrit, dan sikap jujur artinya menyatakan sesuatu itu benar menurut apa adanya, dan menjauhi yang tidak benar dan tidak patut.

\section{Standar Perilaku Etis Notaris}

Secara filosofis terdapat parameter yang beragam dalam menentukan ukuran terhadap perilaku etis notaris, dikarenakan belum terdapat ukuran yang bersifat universal yang berlaku di seluruh dunia (Abdul Ghofur Anshori, 2009 : 123). Meskipun demikian ukuran-ukuran yang masih belum bersifat universal tersebut sudah dapat dijabarkan kedalam prinsip-prinsip atau nilai-nilai yang berlaku dan dapat diterapkan pada suatu tempat, waktu dan situasi tertentu yang kurang lebih sepadan. Dalam tataran yang lebih konkrit, dan faktual dapatlah dikatakan bahwa ukuran untuk perilaku etis notaris adalah apa yang disebut sebagai kode etik notaris (Abdul Ghofur Anshori, 2009 : 123). Meskipun kode etik notaris tersebut dalam tataran praksis menimbulkan persoalanpersoalan yang menyangkut soal otoritas mana yang dianggap berwenang membuat penafsiran terhadap teks kode etik notaris tersebut, namun kode etik tersebut sudah dapat dipergunakan sebagai pedoman guna menentukan apakah seorang notaris tersebut berperlaku etis atau tidak etis.

Etika berasal dari bahasa Yunani kuno ethos, yang artinya ilmu tentang norma-norma hidup. Dalam bahasa Inggris disebut ethic. Sedangkan pengertian dalam bentuk bahasa Indonesia adalah tata susila (kesusilaan, akhlak). Yang dimaksud etika adalah segala peraturan yang mengandung petunjuk bagaimana sebaiknya manusia bertingkah laku. Etika meliputi peraturanperaturan tentang agama, kesusilaan, hukum dan adat. Sedangkan etika dalam arti sempit adalah yang dimaksud dengan Kode Etik Profesi (Wawan Tunggul Alam : 2004 : 22). Dalam Kamus Besar Bahasa Indonesia terbitan Departemen Pendidikan dan Kebudayaan (1988), Etika dirumuskan dalam tiga arti, yaitu:(1) IImu tentang apa yang baik dan apa yang buruk dan tentang hak dan kewajiban moral (akhlak); (2) Kumpulan asas atau nilai yang berkenaan dengan akhlak

(3) Nilai mengenai benar dan salah yang dianut suatu golongan atau masyarakat.Dengan demikian, pengertian etika dapat dirumuskan sebagai berikut:(1) Etika dipakai dalam arti: nilai-nilai dan norma-norma moral yang menjadi pegangan bagi seseorang atau suatu kelompok dalam mengatur tingkah lakunya. Arti ini disebut juga sebagai "sistem nilai" dalam hidup manusia perseorangan atau hidup bermasyarakat. Misalnya Etika orang Jawa. Etika agama Budha.(2) Etika dipakai dalam arti: kumpulan asas atau nilai moral. Yang dimaksud di sini adalah kode etik, misalnya: Kode Etik Notaris Indonesia. (3) Etika dipakai dalam arti: ilmu tentang yang baik atau yang buruk. Arti Etika di sini sama dengan filsafat moral.Dihubungkan dengan Etika Profesi Hukum, Etika dalam arti pertama dan kedua adalah relevan karena kedua arti tersebut berkenaan dengan perilaku seseorang atau kelompok profesi hukum. Misalnya notaris tidak bermoral, artinya perbuatan notaris itu melanggar nilai-nilai dan norma-norma moral yang berlaku dalam kelompok profesi notaris. Dihubungkan dengan arti yang kedua, etika profesi hukum berarti Kode Etik Profesi Hukum. Salah satu contohnya di sini adalah yang disebut dengan Kode Etik Notaris. Kode Etik dalam arti materiil adalah norma atau peraturan yang praktis baik tertulis maupun tidak tertulis mengenai etika berkaitan dengan sikap serta pengambilan keputusan hal-hal fundamental dari nilai dan standar perilaku orang yang dinilai baik atau buruk dalam menjalankan profesinya yang secara mandiri dirumuskan, ditetapkan dan ditegakkan oleh organisasi profesi.

Kode Etik Notaris merupakan suatu kaidah moral yang ditentukan oleh perkumpulan Ikatan Notaris Indonesia berdasarkan Keputusan Kongres Perkumpulan dan/atau yang ditentukan dan diatur dalam peraturan perundang-undangan yang mengatur tentang hal itu dan yang berlaku bagi serta wajib ditaati oleh setiap dan semua anggota perkumpulan dan semua orang yang menjalankan tugas dan jabatan sebagai Notaris.

Pasal 83 ayat (1) Undang-Undang Jabatan Notaris (UUJN) menyatakan bahwa "Organisasi Notaris menetapkan dan menegakkan Kode Etik Notaris". Ketentuan tersebut di atas ditindaklanjuti dengan ketentuan Pasal 13 ayat (1) Anggaran Dasar Ikatan Notaris Indonesia yang menyatakan: "Untuk menjaga kehormatan dan keluhuran martabat jabatan notaries, Perkumpulan mempunyai Kode Etik Notaris yang ditetapkan oleh Kongres dan merupakan kaidah moral yang wajib ditaati oleh setiap anggota Perkumpulan". Kode Etik Notaris dilandasi oleh kenyataan bahwa Notaris sebagai pengemban profesi adalah orang yang memiliki keahlian dan keilmuan dalam bidang kenotariatan, sehingga mampu memenuhi kebutuhan masyarakat yang memerlukan pelayanan dalam bidang kenotariatan. Secara pribadi Notaris bertanggungjawab atas mutu pelayanan jasa yang diberikannya. 
Spirit Kode Etik Notaris adalah penghormatan terhadap martabat manusia pada umumnya dan martabat Notaris pada khususnya. Dengan dijiwai pelayanan yang berintikan "penghormatan terhadap martabat manusia pada umumnya dan martabat Notaris pada khususnya", maka pengemban Profesi Notaris mempunyai ciriciri mandiri dan tidak memihak; tidak mengacu pamrih; rasionalitas dalam arti mengacu pada kebenaran obyektif; spesifitas fungsional serta solidaritas antar sesama rekan seprofesi.Lebih jauh, dikarenakan Notaris merupakan profesi yang menjalankan sebagian kekuasaan negara di bidang hukum privat dan mempunyai peranan penting dalam membuat akta otentik yang mempunyai kekuatan pembuktian sempurna dan oleh karena jabatan Notaris merupakan jabatan kepercayaan, maka seorang Notaris harus mempunyai perilaku yang baik.

Menurut Franz Magnis Suseno dkk terdapat dua prinsip etika profesi luhur yaitu mendahulukan kepentingan klien dan pengabdian pada tuntutan luhur profesi (Abdul Ghofur Anshori, 2009: 62). Para profesional wajib membaktikan keahliannya semata-mata pada kepentingan yang mereka layani, tanpa mempedulikan untung ruginya. Sekalipun seorang profesional berhak bisa hidup dari profesinya, namun pembayaran tersebut tidak boleh menjadi tujuan utama dari pelaksanaan profesinya. Profesi notaris harus dijalankan sesuai dengan pengabdian pada tuntutan luhur profesi. Tuntutan luhur profesi dalam bidang notariat adalah membuat suatu akta yang di dalamnya menentukan hak dan kewajiban tertentu. Dalam kaitan ini yang menjadi landasan utama dalam melakukan pengabdian terhadap tuntutan luhur profesi adalah kebenaran. Kebenaran di sini harus ditinjau dari segi hakikat hukum dan fakta yang disajikan. Fakta hukum adalah fakta yang menimbulkan akibat hukum ( Herlien Budiono, 2011 :1). Karena itu demi perlindungan hukum bagi para pihak dan orang-orang lain yang terikat dari suatu perjanjian yang melibatkan notaris misalnya, maka sebuah fakta hukum harus difahami secara komprehensif guna memperoleh suatu kebenaran.

Profesi notaris sebagai profesi luhur terikat pada moralitas profesi luhur karena tuntutan etika profesi luhur jelas sekali menuntut kejelasan dan kekuatan moral yang tinggi. Franz Magnis Suseno mencatat terdapat tiga ciri dari moralitas profesi luhur yakni berbuat dengan bertekad, kesadaran berkewajiban dan idealisme (Abdul Ghofur Anshori : 63) . Seorang profesional harus memiliki kepribadian yang kuat, dia bukan orang yang mengikuti perasaan dan emosinya saja. Kepribadian moralitas yang kuat tersebut harus muncul dari kesadaran berkewajiban, bukan sekedar dari lingkungan yang mewajibkan tetapi karena keyakinan yang mendalam bahwa tuntutan profesi itu merupakan kewajiban yang berat. Demikian juga dengan idealisme yang berarti dalam sikap dan tindakan ditentukan oleh motivasi untuk melaksanakan cita-cita luhur. Idealisme dalam arti bahwa seorang profesional akan sungguh-sungguh, tanpa pamrih, bersedia melayani sesama menurut jalur-jalur profesinya.

Perilaku Notaris yang baik dapat diperoleh dengan berlandaskan pada Kode Etik Notaris. Dengan demikian, maka Kode Etik Notaris mengatur mengenai hal-hal yang harus ditaati oleh seorang Notaris dalam menjalankan jabatannya dan juga di luar menjalankan jabatannya.

Pasal 83 ayat (1) UUJN menyatakan: "Organisasi Notaris menetapkan dan menegakkan Kode Etik Notaris". Atas dasar ketentuan Pasal 83 ayat (1) UUJN tersebut Ikatan Notaris Indonesia pada Kongres Luar Biasa di Bandung pada tanggal 27 Januari 2005, telah menetapkan Kode Etik yang terdapat dalam Pasal 13 Anggaran Dasar:

a. Untuk menjaga kehormatan dan keluhuran martabat jabatan Notaris, Perkumpulan mempunyai Kode Etik yang ditetapkan oleh Kongres dan merupakan kaidah moral yang wajib ditaati oleh setiap anggota perkumpulan.

b. Dewan Kehormatan melakukan upaya-upaya untuk menegakkan Kode Etik.

c. Pengurus perkumpulan dan/atau Dewan Kehormatan bekerjasama dan berkoordinasi dengan Majelis Pengawas untuk melakukan upaya penegakkan Kode Etik.

Hubungan antara notaris dengan klien adalah hubungan yang bersifat personal, yaitu hubungan antar subyek pendukung nilai, karena itu secara pribadi notaris bertanggungjawab terhadap mutu pelayanan dan jasanya.

Secara formal yuridis kedudukan notaris dan klien adalah sejajar, sama dan seimbang. Namun secara sosio psikologis dalam hubungan itu terdapat ketidakseimbangan disebabkan oleh ketidakmampuan klien untuk dapat menilai secara obyektif pelaksanaan kompetensi pengemban profesi (notaris) yang dimintai pelayanan profesionalnya. Jadi hubungan horizontal antara pengemban profesi (notaris) dan kliennya sesungguhnya merupakan hubungan atas dasar "kepercayaan", oleh karena itu notaris dalam menjalankan profesinya dituntut untuk menjiwai dengan sikap etis tertentu, yang disebut dengan etika profesi.

Disamping hubungan horizontal antara notaris dan kliennya, seorang notaris juga harus 
memperhatikan hubungan vertikal antara manusia dengan Tuhannya. Hubungan antara manusia dengan Tuhannya adalah merupakan hubungan personal vertikal yang berlandaskan kepada kepercayaan kepada Tuhan yang mengharuskan adanya cinta kasih sesama manusia.Hubungan vertikal ini merupakan akar dari hubungan personal horizontal sesama manusia yang bersifat kepercayaan kepada Tuhan. Sehingga seseorang akan termotivasi untuk menghayati profesi sebagai fungsi kemasyarakatan dan memotivasi untuk mewujudkan etika profesi sebagai sikap hidup dalam melaksanakan tugas profesinya.

Etika profesi adalah sebagai sikap etis, sebagai bagian integral dari sikap hidup dalam menjalankan kehidupan sebagai pengemban profesi notaris. Kepatuhan pada etika profesi adalah tergantung pada akhlak notaris yang bersangkutan, karena orang awam tidak dapat menilai apa yang dilakukan oleh notaris dalam menjalankan profesinya, maka notaris itu sendiri membutuhkan pedoman obyektif lebih konkrit bagi perilaku profesionalnya yang diwujudkan dalam seperangkat kaedah atau norma perilaku yang berlaku sebagai pedoman yang harus dipatuhi, yang disebut sebagai kode etik profesi, baik secara tertulis maupun tidak tertulis.

Kode etik profesi merupakan kaedah etika, atau aturan moral positif yang bertujuan untuk menjaga martabat profesi yang bersangkutan dan di lain pihak bertujuan untuk melindungi klien dari penyalahgunaan keahlian dan otoritas dari pengemban profesi tersebut. Profesi hukum sangat berkaitan dengan masalah untuk mewujudkan dan memelihara ketertiban yang berkeadilan di dalam kehidupan masyarakat. Penghormatan terhadap martabat manusia merupakan titik tolak atau landasan tujuan akhir dari hukum. Dalam mewujudkan ketertiban yang berkeadilan, hukum menjadi sarana untuk mewujudkan berbagai kaedah perilaku masyarakat yang disebut sebagai kaedah hukum.

Suatu kaedah hukum harus dibedakan dengan kaedah etika atau moral, karena etika merupakan suatu pengetahuan tentang kebaikan yang tertinggi. Kaedahnya harus diikuti karena kaedahnya merupakan sesuatu yang baik. Sedangkan kaedah hukum adalah suatu kaedah yang menentukan apa yang layak untuk waktu dan tempat tertentu.Hukum lebih memperhatikan hubungan sosial manusia daripada kebaikan dan watak individu dan memperhatikan kesesuaian perbuatan manusia dengan ukuran-ukuran tertentu dan jarang memperhatikan motif manusia.
Etika tidak hanya mempelajari individu atau hanya memperhatikan "batin" dan hukum yang memperhatikan yang "lahir" saja, karena etika juga dalam memperhatikan perbuatan harus memandang akibat-akibat yang timbul dari perbuatan itu. Tidaklah mungkin menganalisa kewajiban-kewajiban etis manusia tanpa memperhatikan kewajibannya terhadap sesamanya atau kedudukannya dalam masyarakat. Hukum mengatur tingkah laku manusia agar sesuai dengan hukum dan mendasarkan pertanggungjawaban dengan sanksi, agar orang tidak berbuat yang bertentangan dengan hukum, sedangkan etis, letak pertanggungjawabannya pada kesukarelaan seseorang untuk berperilaku sesuai dengan ketentuan "etika". Jadi hanya berdasarkan tuntutan batin seseorang untuk mentaati norma-norma etika itu, namun demikian aturan etika itu menyempurnakan aturan hukum.

Kode etik profesi merupakan kriteria prinsip profesional yang telah digariskan, sehingga dapat diketahui dengan pasti kewajiban profesional anggota lama, baru, atau calon anggota kelompok profesi. Kode Etik Profesi dibuat tertulis, karena mempunyai fungsi sebagai sarana kontrol sosial, sebagai pencegah campur tangan pihak lain dan sebagai pencegah kesalahpahaman dan konflik. Dengan demikian dapat dicegah kemungkinan terjadinya konflik kepentingan antara sesama anggota kelompok profesi, atau antara anggota kelompok profesi dan masyarakat.

Anggota kelompok profesi atau anggota masyarakat dapat melakukan kontrol melalui rumusan kode etik profesi, apakah anggota kelompok profesi telah memenuhi kewajiban profesionalnya sesuai dengan kode etik profesi. Pemerintah atau masyarakat tidak perlu campur tangan untuk menentukan bagaimana seharusnya anggota kelompok notaris melaksanakan kewajibannya. Kode etik notaris dapat mencegah kesalahpahaman dan konflik. Kode etik notaris yang baik adalah yang mencerminkan nilai moral anggota kelompok notaris sendiri dan pihak yang membutuhkan pelayanan profesi yang bersangkutan. Oleh karena itu dalam hal penegakan kode etik notaris, integritas dan komitmen haruslah menjadi taruhannya demi terjaganya citra profesi notaris itu sendiri. Penegakan kode etik diartikan sebagai kemampuan komunitas notaris dan organisasinya untuk memaksakan kepatuhan atas ketentuan-ketentuan etika bagi para anggotanya, memproses dugaan terjadinya pelanggaran kode etik dan menindak anggota yang melanggar ketentuan-ketentuan yang tercantum didalamnya. Guna menjaga dan mempertahankan kualitas 
para anggotanya, sebuah organisasi notaris harus memperhatikan kompetensi intelektual para anggotanya agar lebih baik lagi kualitas pelayanannya kepada masyarakat.

\section{d. Faktor-Faktor yang Mempengaruhi Perilaku Etis Notaris}

Perilaku etis notaris dipengaruhi oleh banyak faktor yang dapat dijabarkan sebagai berikut: (Abdul Ghofur Anshori, 2009 : 155-159). Pertama, adalah faktor intepretasi hukum, yang merupakan faktor internal perilaku etis seorang notaris. Pemahaman mengenai apa yang disebut sebagai hukum akan menentukan seperti apakah perilaku etis notaris itu. Intepretasi hukum dalam konteks etika menunjukkan bahwa hukum bukanlah sarana untuk merekayasa masyarakat dengan suatu paksaan, melainkan sebagai sarana tertib masyarakat dengan suatu penerimaan yang berupa kerelaan. Intepretasi hukum dapat mewujud dalam banyak aspek namun salah satu hal yang terpenting adalah melihat hukum dari perspektif asal-usulnya. Dalam masyarakat sekuler, inteprestasi hukum didasarkan pada nilai-nilai dan standar kontemporer yang seringkali berbeda-beda, sementara dalam masyarakat religius, hukum didasarkan pada nilai-nilai agama yang bersifat dogmatik dan universal. Kedua, tahap perkembangan moral, yang dapat dilihat melalui struktur kesadaran manusia sebagaimana teori psikoanalisis Sigmund Freud (1856-1939). Freud mengidentifikasikan unsur-unsur utama dalam kesadaran manusia sebagai Id, Ego, dan Superego. Ajaran Sigmund Freud mengenai tahap perkembangan moral sejalan dengan konsepsi Timur yang menyatakan bahwa jiwa manusia dalam perkembangannya dapat dijelaskan melalui tiga variabel, yakni tahap ammarah, lawwamah, dan muthmainnah. Tahap ammarah adalah tahap ketika jiwa cenderung pada perbuatan jahat, dan jika tidak dikontrol atau dijaga, akan menyeret pada kemungkaran. Tahap lawwamah adalah tahap perasaan akan kesadaran atas kejahatan, dan untuk menahannya dengan melakukan perbuatan pencegahan. Salah satu cara yang dilakukan adalah dengan bermunajat memohon kemurahan dan ampunan Allah setelah bertaubat dan menjauhinya, sehingga diharapkan akan memperoleh keselamatan. Muthmainah adalah tahap yang tertinggi, yaitu ketika jiwa mencapai kepenuhan hati dan kepuasan setelah akal dibersihkan dari kecenderungan jahat manusia. Jika notaris berperilaku secara tidak etis maka dapat dikatakan bahwa pada saat itu notaris yang bersangkutan berada dalam kondisi nafs ammarah atau dalam keadaan Ego tidak dapat menguasai Id. Ketiga adalah Nilai Pribadi dan Personalitas. Nilai-nilai dan moralitas individu juga akan mempengaruhi standar etika seseorang. Seseorang yang menekankan sifat jujur akan berperilaku sangat berbeda dari orang yang tidak menghargai hak milik orang lain. Dalam hal ini variabel kunci kepribadian yang mempengaruhi perilaku etis seorang individu adalah kemampuannya mengendalikan diri. Seorang individu memiliki kemampuan mengendalikan diri secara internal jika individu tersebut percaya bahwa ia dapat mengontrol berbagai hal dalam kehidupannya. Sebagai konsekuensinya, individu dengan keyakinan internal ini akan merasa bertanggung jawab terhadap segala bentuk tindakannya. Sebaliknya, seorang individu yang mempunyai kemampuan mengendalikan diri secara eksternal, percaya bahwa nasib dan keberuntungan, atau orang lain, yang mempengaruhi hidupnya. Individu seperti ini cenderung percaya bahwa kekuatan eksternal yang menyebabkan berperilaku etis atau tidak. Secara keseluruhan, mereka yang berkeyakinan internal akan cenderung untuk membuat keputusan-keputusan etis daripada mereka yang berkeyakinan eksternal. Mereka lebih sulit dipaksa bertindak secara tidak etis, dan akan menolak untuk melukai orang lain, bahkan meskipun ketika diminta oleh orang lain yang kedudukannya lebih tinggi. Keempat adalah Motivasi. Motivasi dapat menguatkan atau memperlemah/ mengurangi tingkat moralitas suatu perbuatan. Motivasi merupakan suatu niat untuk berbuat sesuatu. Melalui niat ini dapat ditelusur apakah suatu perbuatan adalah etis ataukah tidak. Etika menghendaki antara niat, sarana atau cara dan hasil merupakan suatu hal yang selaras. Ketidakselarasan antara ketiga elemen tersebut menjadikan adanya cacat periaku sehingga perilaku tersebut tidaklah dapat dikategorikan sebagai suatu perilaku yang etis. Kelima adalah tujuan akhir dari suatu perilaku yang merupakan faktor internal yang penting dalam menentukan suatu tindakan manusia. Sasaran adalah perwujudan dari perbuatan itu sendiri, yaitu perbuatan yang dikehendaki secara bebas menurut aturan moral. Moralitas pada dasarnya terletak pada kehendak. Di dalam menghendaki, manusia menghendaki sesuatu, sehingga pada akhirnya perbuatan itu menjadi obyek perhatian kehendak. Perbuatan manusiawi mendapatkan moralitas pertamanya dari hakikat perbuatan yang senyatanya dikehendaki oleh pelakunya untuk dilakukan, dalam hal ini perbuatan yang dilakukan dan motivasinya berbaur. 
Selain faktor internal sebagaimana diuraikan di atas, juga terdapat faktor dari luar. Faktor eksternal adalah apa saja yang dapat mempengaruhi suatu perilaku etis notaris yang bukan berasal dari pribadi, namun dari lingkungan yang ada di sekitarnya sepanjang manusia hidup. Faktor eksternal ini merupakan ruang lingkup atau lingkungan perbuatan, ialah segala sesuatu yang secara aksidental mengelilingi dan mewarnai perbuatan. Meskipun faktor eksternal ini tidak semuanya pada kenyataannya mempengaruhi suatu perilaku etis, namun faktor eksternal ini merupakan pendorong yang dapat mempengaruhi suatu perilaku baik secara langsung maupun tidak langsung. Antara faktor eksternal dan internal seringkali terjadi tarik ulur mengenai apa yang semestinya dilakukan dan seseorang yang berusaha untuk berperilaku etis akan memilih perilaku yang sesuai dengan fitrahnya (hakikat) sebagai manusia dan tidak menafikan dorongandorongan hati untuk selalu berbuat kebaikan. Faktor eksternal ini dapat berupa pengaruh keluarga, pengalaman hidup, teman sebaya, organisasi, faktor situasional dan faktor-faktor lainnya yang berasal dari lingkungan notaris yang bersangkutan.

\section{E. Simpulan}

Dalam mengemban tugasnya selaku profesional, seorang notaris terikat berbagai norma dan nilai yang merupakan parameter dalam berperilaku secara etis. Secara filosofis, belum terdapat ukuran yang bersifat universal yang berlaku di seluruh dunia tentang parameter yang dapat dijadikan sebagai ukuran perilaku etis notaris. Meskipun demikian hal tersebut sudah dapat dijabarkan kedalam prinsip- prinsip atau nilai-nilai yang berlaku dan dapat diterapkan pada suatu tempat, waktu dan situasi tertentu yang kurang lebih sepadan. Dalam tataran yang lebih konkrit, dan faktual ukuran untuk perilaku etis notaris adalah apa yang disebut sebagai kode etik notaris. Akhirnya agar terwujud sebuah perilaku etis, diperlukan integritas dan komitmen bersama dalam proses penegakan substansi Kode Etik Notaris melalui mekanisme yang telah disepakati bersama. Proses ini harus dilakukan secara terus menerus sehingga terbangun standar perilaku etis yang bisa menjadi pedoman berperilaku yang bukan hanya bersumber dari teks dalam Kode Etik Notaris, melainkan juga dari pemahaman secara kontekstual terhadap implementasi Kode Etik Notaris tersebut. Kode Etik Notaris sebagai satusatunya parameter perilaku etis Notaris dalam arti yang paling faktual, hendaknya selalu disesuaikan dengan perkembangan dinamika yang terjadi di lingkungan masyarakat, agar eksistensi nilai-nilai yang terkandung di dalamnya tetap terjaga. 


\section{daftar Pustaka}

Abdul Ghofur Anshori. 2009. Lembaga Kenotariatan Indonesia (Perspektif Hukum dan Etika). Yogyakarta: UII Press.

Abdulkadir Muhammad. 2001. Etika profesi Hukum. Bandung: Citra Aditya Bakti.

Badudu-Zain. 1994. Kamus Umum Bahasa Indonesia. Jakarta: Pustaka Sinar harapan.

Frans Magnis Suseno. 2001. Etika Jawa. Jakarta: Gramedia.

Habib Adjie. 2009. Hukum Notaris Indonesia (Tafsir Tematik Terhadap UU No.30 Tahun 2004 tentang Jabatan Notaris). Bandung: Refika Aditama.

. 2008. Sanksi Perdata dan Administratif Terhadap Notaris Sebagai Pejabat Publik. Bandung: PT Refika Aditama.

2011. Majelis pengawas Notaris Sebagai pejabat Tata Usaha Negara. Bandung: PT Refika Aditama.

Herlien Budiono. 2011. Ajaran Umum Hukum Perjanjian dan Penerapannya di Bidang Kenotariatan. Bandung: PT Citra Aditya Bakti.

Kamus Terbaru Bahasa Indonesia Tahun 2008. Surabaya: Reality Publisher.

Kode Etik Notaris Indonesia

Kitab Undang-Undang Hukum Perdata

Louiss O. Kattsoft. 1987. Element of phylosophy (pengantar Filsafat), alih bahasa Soejono Soemargono, Yogyakarta, Tiara Wacana

Muchsin. 2004. Ikhitisar Materi pokok Filsafat Hukum. Jakarta : STIH "IBLAM"

Sumaryono, E .1995. Etika profesi Hukum, Norma-Norma Bagi penegak Hukum. Yogyakarta: Kanisius.

O. Notohamidojo. 1975. Soal-Soal pokok Filsafat Hukum. Jakarta: BPK Gunung Mulia.

Otje Salman. 2010. Filsafat Hukum (perkembangan \& Dinamika Masalah), Bandung : Refika Aditama

Tan Thong Kie. 2007. Studi Notariat dan Serba- Serbi praktek Notaris. Jakarta : PT Ichtiar Baru Van Hoeve.

Theo Huijbers. 1995. Filsafat Hukum. Yogyakarta: Kanisius

Undang-Undang No. 30 tahun 2004 Tentang Jabatan Notaris

Wawan Tunggul Alam. 2004. Memahami Profesi Hukum ( Hakim, Jaksa, Polisi, Notaris, Advokat dan Konsultan Hukum pasar Modal ). Jakarta: Milenia Populer.

144 Yustisia Vol.2 No.3 September - Desember 2013 Kajian Filosofis Terhadap Standar Perilaku ... 